\title{
建築雑誌に示された日本の建築界への「空間」という概念の 導入と定着 \\ T.HE INTRODUCTION AND DEVELOPMENT OF THE CONCEPT OF "SPACE" AMONG JAPANESE ARCHITECTS SHOWN IN THE FOUR MAJOR. ARCHITECTURAL MAGAZINES BETWEEN 1887 AND 1960
}

\author{
藤 岡 洋 保*, 佐 藤由 美** \\ Hiroyasu FUJIOKA and Yumi SATO
}

\begin{abstract}
This paper shows how the concept of "space", which was first developed in Germany in the late 19th century, was introduced into and developed in Japan, analyzing the articles on the four major Japanese architectural magazines between 1887 and 1960. Until the 1920s; the word kukan (space) had rarely been used in them. The concept of "space" began to be developed in the 1930s. From the 1950s on, it has been utilized by Japanese architects, especially the team led by Kenzo Tange. Their move implies that at that time modern rationalism began to gain ground in many Japanese architects' thoughts.
\end{abstract}

Keywords : space, Japanese modern architecture, modern rationalism 空間; 日本近代建築, 近代合理主義

\section{1. 緒 言}

今日の日本の建築界では，「空間」は建築を語る上で 必須の概念といっていい。建築意匠に関する文献に「空 間」という語は頻繁に登場するし，研究者だけではなく， 建築家もこの語を常用している。

しかし，建築においては，この「空間」という概念は ヨーロッパにおいても日本においても古くから親しまれ ていたわけではない。

コルネリス・ファン・デ・フェンの「築の空間】 (佐々木宏訳, 丸善, 1981 年) によれば, 「古代以来, 空間理念は一般に哲学や自然科学の重要な論議の問題と されていた。しかも全く奇妙なことに建築理論の中では ごく最近になって現われてきた。実際のところ19 世紀 後半以前には, ひとつとしてそれについての建築理論は 見当たらない」(p.v)。すなわち，「空間」は哲学や自 然科学の分野では古代から重要な関心事だったが，それ が建築を分析する際の主要な概念として認識されるよう になったのは，すなわち，ファン・デ・フェンにしたが えば，「空間理念が建築の基本であるという考え方が導 入された」(p.viii) のは, 19 世紀の後半だったのである。
ファン・デ・フェンは，このような考え方を最初に公式 に表明したのはアドルフ・フォン・ヒルデブラントやア ウグスト・シュマルゾウで, 彼らはともに 1893 年にそ れを著書で示した (p. x)，と述べている。

上松佑二は『建築空間論 その美学的考察」(早稲田 大学出版会, 1986 年) で,「空間』の理念が『建築の 生命』として意識的に登場するためには，やはり，ヤー コプ・ブルクハルトを待たなければならなかった」 (p.18) と，1855 年のブルクハルトの著作『チチェロー 祀にその嚆矢を見ている。之同時に上松も，「ヴェル フリンをはじめ十九世紀末から今世紀初頭の芸術学者に 決定的な影響を与えたのは，アドルフ・フォン・ヒルデ ブラントの『造形芸術における形式の問題』(一八九三) である。自らの彫刻家としての体験が, 造形芸術におけ る空間とフォルムの問題に創作美学からの的確な表現を 与えている」(p.22) と, ファン・デ・フェン同様,「空 間」が建築を語る際の主要な概念として注目されはじめ たのは 19 世紀末のドイツ語圏においてであったことを 指摘している。

この概念は日本の建築界にも導入され，やがて建築を

\footnotetext{
* 東京工業大学工学部一般教育等図学 助教授·工博 Assoc. Prof., Sec. of Descriptive Geometry, Faculty of Eng.,: Tokyo Institute of Technology, Dr. Eng.

** 建設省東北地方建設局 ·工修 Ministry of Construction, Tohoku Regional Construction Bureau, M. Eng.
} 
語る際に活用されることになる。「空間」という概念で 建築を語ることは,「室」や「建物」,「庭園」などの語 を用いる思考法よりも，抽象的なレベルで建築や環境を 見る行為といえる。つまり可視的なもの (表層)ではな く，その背後にあると考えられる「空間」という抽象的 なものに建築の本質を見るということである。そこには 建築の成り立ちに対する関心があり，この概念を展開す ることによって「空間の分節」とか,「空間の連結」「内 部空間」,「外部空間」といったような, 表層を超えた普 遍的なレベルでの考察が可能になる。

抽象的・普遍的なものを本質と見るこのような思考法 は近代（主義）建築の基盤である近代合理主義の特徵の 一つである。近代合理主義は表層よりもその背後に潜む と考えられる普遍的要素を重視する。通常, 建築におい ては「空間」という概念は茫漠とした単なる三次元的な 拡がりをさすのではなく, 何らかの知的操作によって分 節され価値を付与された三次元的なまとまり，として認 識されているといってよかろう。つまり，「空間」は人 間の理性によって認知され得るものであり，「空間」に 建築の基本原理を見るという行為は建築を成り立たせて いると考えられる普遍的要素に対する高い関心，いいか えれば合理主義的思考に支えられている。この概念が 19 世紀後半に建築を語るのに導入され，やがて頻用さ れるようになったことは近代合理主義の興隆，そしてそ れを基盤にした近代（主義）建築の台頭と無関係ではな い。したがって，この「空間」という概念が日本の建築 界に導入され定着していく過程を歴史的に追うことは近 代合理主義的思考，すなわち，近代（主義）建築の思想 的基盤，が日本にどのように導入され定着していったの かをあとづける試みの一つとして位置づけることができ ると考えられる。

本研究は，以上の上うな認識のもとに，「空間」とい う概念が日本の建築界でどのように展開されたのかにつ いて分析しつつ, そこに見られる特徵について考察した ものである。すなわち，「空間」という概念そのものを 問題にするのではなく，「空間」という概念が導入され 活用されていく過程に注目するのである。その目的は, 「空間」を近代合理主義のキー・ワードの一つと見て, その導入・活用の過程を通して日本の建築界における近 代合理主義的思考の導入・理解のされ方の一端をさぐろ うとするところにある。

その対象になり得る史料の数は膨大である。これまで に日本語で書かれたすべての建築文献が該当し得る。理 想的にはそのすべてを収集・分析すべきだが，実際には かなりむずかしいので，本研究では，通時的に見ること を意図して，比較的長期にわたって発行された建築雑誌 4 誌を主な分析対象にした。具体的には, 『建築雑誌』。 『建築世界』・国際建築』(1927 年 5 月号までは『国際
建築時論』)・新建築』”を通覧した。『建築工芸アイシー オール』など, 分析の過程で必要と思われたものにも適 宜目を通した。当時の辞典や辞書なども参考にしている。 研究の範囲は 1887 (明治 20）年から1960（昭和 35） 年までとした。1887 年からとしたのは分析対象にした 建築雑誌のうち最も古い『建築雑誌】の創刊にあわせた ためである。また，1960 年までとしたのは，予備的な 調查で「空間」という語が日本の建築文献によく用いら れるようになるのが戦後であることがかなり予想できた こと，そして活用されるようになった経緯や背景を分 析・考察するのに 1960 年までをとれば十分な資料が得 られると考えたからである。

研究の方法としては，まず「空間」という語に注目し た。「空間」という概念を適用する場合には当然ながら この語を使用することになるからである。ちなみに，「空 隙」とか「スペース」のような当時の文献に登場する類 似の語にも注意をはらった。そして，「空間」やそれに 類似する語が登場する文献を悉皆的に収集し，そこでの 用いられ方を分析した。

本研究では主な資料を 4 種の建築雑誌に限っているの で，そこから日本の建築界における「空間」の扱い方に ついて普遍的な見解が得られるわけではない。しかし， そのような限定つきではあるが，このテーマについての 研究の端緒を開こうとする試みという点での意義はある 之筆者らは考えている。

ちなみに, 英語の space, ドイツ語の raumに対応す る語としての「空間」が明治中期に存在していたことは 確かである。たとえば，1881（明治 14）年発行の『哲 学辞巢」(井上哲次郎, 東京大学三学部印行) は英語の 哲学用語に対応する日本語の翻訳を揭載したものだが, そこに「space 空間」(p.86) と記されている。また， 1886 (明治 19）年発行の「独英和 三対字彙大全』(高 良二・寺田勇吉共訳，共同館）には「Raum, m. (-es； pl Raume) room, space, place, hold of a ship, 場所, 空所, 空間, 明キ, 余地, 室, 艙二ベヤ (以下略)」(p.1019) とある。

\section{1940 年頃までの「空間」という語を用いた記述}

分析対象に選んだ建築雑誌の中でもっとも早くから発 行されているのは建築学会の機関誌『建築雑誌』である。 『建築雑誌』に「空間」という語が使われた例はかなり 早くから見いだすことができる。その初出は1890（明治 23）年 3 月号の「室内採温法」で,「背後モ鉄板 7 用七 テイナル三时巾ノ空間ヨ置キカクテ背後卜両妻ノ後及ヒ 灰止下ノ空間八相通シ（中略）又冷気ハハヨリ入リティ イナル空間ニ入リ」(p.35) という記述の中に見られる。

しかし, 戦前の, それも特に明治・大正時代の『建築 雑誌』においては「空間」という語は稀にしか登場しな 
い。1927（昭和 2）年までは「空間」やそれに類似する 語を用いた記事の数は年間で最大でも 4 例 (1917 年) にすぎず，まったく見られない巻もある。

1907 (明治 40) 年創刊の『建築世界」においても同 様で, 1909 (明治 42) 年にはじめて「空間」という語 を用いた記事 ${ }^{2)}$ が登場し（この年には他に 2 件ある)， その後 1914（大正 3）年までは全体で 1 件しかなく, 1915（大正 4）年から1926（大正 15）年までは「空間」 という語を用いた記事は各年に 2 件から 10 件だけであ る。

しかも，この時代の『建築雑誌』・健築世界』におけ る「空間」という語はまず例外なく一つの記事の中に 1 か所または数か所唐突に登場するだけで，しかもそのほ とんどは，「畢竟上図組物備への間に生ずる異様なる空 間を充填するの意味を有するものなるを以てCなる空間 は其大体に就て組物と蟇股との輪郭を画せる $\mathrm{AB}$ なる 並行線を以て之を限れると見るべく」旻とか，「第二に空 き間 (Spaces) と繰り形に応じて, 模様の当てハメ方 が当を得たること」市のように，「物と物との間」や「す きま」「あるまとまりをもった広がり」を指示するため に用いられているにすぎず，建築を語る上での主要な概 念として扱われていると考えられる例を見いだすことは できない。

ちなみに，上記以外の「空間」の使用例として，数は 少ないが，欧米の建築文献の翻訳や “space” • “raum” の訳語として登場するものがある。それは2つの分野, すなわち建築構造学とドイツ美学・美術史関係のものに 見られる。前者の例としては下記のようなものを上げる ことができる。

-「若し一系内にある全構材及各分格点に働く外力共に同一 平面内にある場合は是を名けて平面架構 (Framed Structure in plane) ど云ひ然らざる場合には是を名けて空間架 構 (Framed Structure in space) と云ふ」

日比忠彦「鉄骨構造建築学 (t)」(「建築雑誌」1907. 年 3 月号, p. 7)

・「檜枠は地階に達する迄全くコンクリート中に埋め, その 間の空間はコンクリート床を張る」

内藤多仲「事務館に於ける耐震構造の一例 エンヂニアリ ングレコード所載（一九一一年八月五日)」(「建築雑誌】 1911 年 9 月号, p. 33)

また，後者の例としては『建築世界」1919 年 7 月号 から翌 20 年 1 月号にかけて連載された「独逸建築略史」 (アーデルバート・マッタイ原著, 鈴木久蔵訳) などが あげられる。その中では「空間感情」とか「空間観念」 のような,ドイツ美学・美術史に特徴的な表現が見られ る5!。翻訳文の中ではないが，ドイツ美学・美術史の流 儀に由来すると思われる「空間」の使用法も散見される。 それは、たとえば，下記のようなものである。

・「建築は美術の一種類である。而して美術を空間芸術と時
間芸術とに分けると前者に属し, 又造形美術の内にも入り， 骰刻，絵画と列を同じうしてるるものである。」

黒田朋信「建築批評の標準」(『建築䧱誌」1911 年 5 月号, p. 3)

・「若し建築を空間を仕切る芸術であるとするならば其内に 人を住ましむるは不合理である。」

野田俊彦「建築非芸術論」(「建築雑誌」1915 年 10 月号, p. 28)

上記の引用のような例は建築美について語るときや他 の芸術，たとえば䧓刻などに言及するときに見られる。 山崎静太郎が『建築雑誌』1914 年 11 月号に書いた「健 築美私論（二)」の「建築と㓮刻」(p.5) の項だけに 5 回「空間」という語が登場するのはそのような傾向を象 徵するものといえる。

以上から，明治・大正時代の日本の建築雑誌において は「空間」という語は稀にしか見られないこと，その多 くは「物と物との間」，「すきま」，「あるまとまりをもつ た広がり」という意味に用いられていること，それ以外 には欧米の建築文献の翻訳の中に登場すること，それに 関連してドイツ美学・美術史の流儀に由来すると思われ るやり方で「空間」を使う例があったことがわかる。こ のことは「空間」という語が欧米，特にドイツ起源のも のとして日本の建築界に導入されつつあったことを示し ている。しかし，明治・大正時代の『建築雑誌』や『建 築世界」にこの「空間」を建築を語る際の主要概念に高 めた例を見いだすことはできない。後藤慶二が『建築雑 誌』1916（大正 5) 年 7 月号に記した以下の文章はその ような当時の状況を象徵するものといえる。

「構造上の問題は即ち科学（狭義の）問題で意匠の問題は芸 術の問題である, 尚之を敷衍すれば前者は空間的の問題で後 者は非空間的の問題である,」(p.36)

後藤慶二「形而下の構造に対する形而上の批判」

ここでは，構造の問題は「空間」の問題だが，意匠の 問題はそうではないと述べられている。

明治・大正時代に比べ，昭和に入ると「空間」という 語の登場頻度は多少高くなる。たとえば，「建築雑誌】 では1928（昭和 3）年から1944（昭和 19）年の間で「空 間」という語が登場する記事の数は年ごとで 2 件から 22 件であるが, その 17 年のうちの 9. 年においては 1 年 間に 10 以上の記事に掲載されている。

1925 (大正 14）年創刊の『国際建築】と『新建築』 はいずれも建築の意匠に関する記事を多く載せているの で，昭和初期における「空間」という語の用いられ方を 検討するのに適した資料といえる。

『国際建築」において「空間」，または「スペース」な どそれに類する語を用いた記事を収集すると，創刊直後 の 4 年間（1928 年まで）はそれぞれ 8 .件，3 件，2. 件， 2 件と少ない。しかし，1929（昭和 4). 年に 18 件登場し てから後は毎年 11 件から 27 件の記事に使われているの 
を見ることができる。件数は『建築雑誌』より多いが, 一つの記事の中に 1 か所または数か所断片的に登場する だけで，「空間」を叙述の中心にすえるようなものが少 ない点では同様である。先に指摘した明治・大正時代の 「空間」という語の使用法と同様,「物と物との間」と か「すきま」，「あるまとまりをもったひろがり」の意味 で使われている例が多い。

それとともに，『国際建築』においては欧米文献の翻 訳や紹介に，また欧米の建築家やその作品に関する記事 に「空間」という語が登場することが多いのが特徴であ る。たとえば，1929（昭和 4）年の同誌における「空間」 という語が用いられた記事 18 件のうち，6件は下記の ような欧米文献の翻訳である。

-「直角は全く正確に空間を決定するに用ひられるが故に」 ル・コルビュジェ/池田英夫訳「ユルバニスム（三）」(国 際建築」1929 年 3 月号, p. 30)

・「そしてその調和のうちに，確実性ある，調和的な凡ての 比例均衡と, 空間, 時間, 材料それ自力の自然性を通して 䈯かれた必要とを均整にした，家屋と云ふものが社会の余 剩的存在から分離された。その上に内部的空間と外部的空 間とを一致調和させた。絵画が建築的構成から区分された 理由はそれに外ならない。色彩は空間の変化の如くに，篇 格に使用されはしない。」

ジャン・バドウィシ／岩崎奇作訳「構成主義者」(「国際建 築」 1929 年 7 月号, p. 9)

また, それ以外の 5 件は, 下記の引用のように, ヨーロッ パの建築家に言及したものである。

・「ファザードから家 (ハウス) から空間の構成へ(ベーネ) の変転と」

川喜田煉七郎「ベーレンスの事業及び作品譜にそへて」(「国 際建築」1929 年 10 月号, p.6)

-「メ氏の説明にある「運動する光の看板の打上げ花火。浮 びまた潜り，飛出しまた消える」乱雑な光の空間がよく表 はれていると思ふ。」

蔵田周忠「国際雑記 (一O)」(「国際建築」1929 年 10 月号, p. 14)

ここに示したような傾向，すなわち欧米の建築文献の 翻訳や欧米の建築家やその作品に関連して「空間」とい う語が登場するという傾向は『国際建築』に一貫して見 られる。そのような傾向を代表するのは蔵田周忠である。 彼は同誌の「国際雑記」㯗などでこの語を用いている。

同様の傾向は『新建築」にも見ることができる。

『新建築』においても「空間」という語は断片的に登 場する。そのほとんどは「特に坊ちゃん嬢ちゃんの葠室 は，寝台車式になってるて，空間を非常に有効に使用し てあります」的のような「あるまとまりをもった広がり」 や「すきま」を意味するか，欧米の建築文献に直接・間 接に関係があるものである。『新建築」においても欧米 文献の翻訳や欧米の建築家への言及の中で「空間」が用 いられることが多い。戦前の『新建築」で「空間」やそ
れに類する語を含む記事が最も多く登場する年は 1940 年で，20件あるが，その中の 15 件がそれに該当する。

以上，『国際建築』・『新建築』を中心に昭和初期にお ける「空間」という語の使われ方について見たが，ここ でも明治・大正時代に関して指摘したの亡同様の傾向を 見てとることができる。すなわち、「空間」という語は「物 と物との間」，「すきま」，「あるまとまりをもった広がり」 という意味で, また欧米の建築文献の翻訳の中や欧米建 築家に言及した文章に用いられている。このことも「空 間」が外来のもので, 欧米の建築家や建築を語ることを 通して，またドイツ美学・美術史の影響を受けながら， しだいに日本の建築文献に浸透していったことを示唆し ていると考えられる7。

\section{3.「空間」を主要概念にした建築分析法の導入と展開}

前章で，昭和初期においても「空間」という語を用い た記述は少ないこと，そのほとんどは「空間」を「物と 物との間」，「すきま」，「あるまとまりを持った広がり」 という意味で用いただけのものか，欧米の建築文献の翻 訳や欧米建築家への言及の中に見られることを指摘した が，昭和初期には「空間」を主要な概念にして建築を語 ろうとする先駆的な試みが見られることにも注意する必 要がある。

調査対象雑誌の中で筆者らが調べ得た限りでは，その 最初の例は四新建築』1927 年 1 月号掲載の元良 勲の「建 築は空間の堆積である」(pp. 54-60) と考えられる。こ の文中には「空間」という語が頻繁に登場し，「屋根や， 柱や，壁や，床が，決して建築そのものではなく，之等 の造り出す空間そのもの>集合，堆積したものが建築の 本体である事を論じて見よう」(p.54) としている。こ こでは「空間」こそが実体であることが主張されている。

同じ『新建築』の1932 年 6 月号掲載の山田 守の「住 宅の一実例 其三」(pp. 201-208) では「住居空間の自 然性恢復」とか,「住居空間の区別 住居空間を分ちて 三とする。1 自然的住居空間 2 半自然的空間 3 人工 的空間」(p. 202) のように, 住宅とその周囲の環境を「空 間」という概念を導入して 3 つに区分している。

また，川喜田煉七郎は『国際建築」1930 年 2 月号揭 載の「第二回国際新建築会議詳報」の中で,「最も合目 的に徹底した住居空間の最小限度」(p.9) のように，「住 居空間」という語を用いている。川喜田はこの頃住宅の 機能に言及するとき，「空間」という語をしばしば使っ ている。それが最も顕著に見られるのは彼を中心につく られた『建筑工芸アイシーオール』の誌上である。1931 (昭和 6) 年 11 月刊行の同誌第 1 巻第 1 号の「近代住 宅の構成 no.1」（pp.1-24）は「十月九日早大建築科主 催の新興建築講演会に於る同人川喜田の講演草稿に輔正 を加へたもの」(p.1) だが，そこではアレキサンダー・ 
クラインの平面分析法に言及しつう，「住居空間」(p.2) とか,「多種多様の空間の連続」(p.8)，「我々の視空間 ならざる触空間の感覚がすべてをよい建築であると感ず るだらうか」(p.11)，「そこで同じ様な共通共同の空間 （視空間・触空間の一切をふくんだ空間）に生活すると いふ心理的な理由で，この数の少ない相似・類似の空間 を我々がもつ事が重要になる」(p.11), 「同じ様な必要 空間の緊密な連続でもって住居を形成すべきである」 (p.11)のように，ひんぱんに「空間」という語が登場 する。ここでは「空間」は単なる「すきま」や「あるま とまりを持った広がり」という以上に, 住宅について考 察する際の重要な概念としても用いられている。この他 にも川喜由は『建築工芸アイシーオール」1935 年 5 月 号の「一住宅一一実験住宅」で「その特殊な用途を持っ た空間が如何に住宅内で連絡してるるか，そしてその大 きな空間同志が又どう連絡してるるかといふ問題を，特 別に取出してみようと思ふ」(p.12) と, 「用途空間」 という概念を導入している。ここにはある機能とそれに 対応する「空間」を軸に住宅をとらえようという姿勢が 見られる。この「空間」は必ずしも「室」である必要は なく，廊下なども含むものとしてとらえられている。

同様の発想で住宅の機能を分析するのに「空間」とい う概念を導入した研究者として注目されるのが西山外三 である。西山は有名な食浸分離論を展開する基礎になっ た研究 ${ }^{8)}$ で,「就寝空間」,「採食空間」という表現を用 いている。ここでは「寝室」とか「食事室」という呼称 が避けられている。これは就寝や食事という行為が実際 に行われる場を的確に表したいという要求にもとづくも のと考えられる。「寝室」や「食事室」のような語では そこで実際に展開される行為を十分には指示できない が,「空間」という概念を導入することで, ある行為に 対応する場を指示することが可能になったのである。

以上に示したように, 行為 (機能) とそれが行われる 場よの対応を指示するために「空間」という概念が川喜 由や西山によって導入・展開された。ここでは「空間」 は建築を語るときの一つの主要な概念になり得ているよ うに思われるが; 特に川喜田の場合, それが十分に咀㗄 されていたかについては疑問が残る。というのは, 『建 築工芸アイシーオール』に掲載された川喜田の文章に「空 間」という語があらわれるのが住宅関係のものにほぼ限 定されているからである。川喜田は商店建築など他の建 築種について同誌に文章を揭載しているが，そこでは， 住宅と同様に機能にも関心が向けられながらも，「空間」 という語はほとんど登場しない。つまり,川喜田が「空 間」という概念を展開するのは住宅の, それも機能にか かわるものに限定されているのである。このことは川喜 田にとって「空間」は（おそらくアレギサダー・クラ インらから ${ }^{9)}$ 与えられた概念のレベルにとよ゙まってお
り，彼自身の思想として血肉化されてはいないことを示 唆するものと考えられる。

「空間」が「借り物」のレベルにとどまっているとい う傾向はこの時期にこの語を用いた山田 守や蔵田周忠 にも指摘できると考えられる。蔵田の文章においては「空 間」は欧米の近代建築に言及するときにほぼ限られてお り, 彼が読んでいたであろう欧米の建贸雑誌の影響を感 じさせる。また，山田の場合には「空間」という語は定 常的に見られるのではなく，いくつかの文章に唐突に登 場する。いずれの場合も「空間」を建築を語る際の主要 な概念にすえるというよりは，欧米の建築文献に影響さ れてこの語を用いているという印象が強い。

先述のように，分析対象にした建築雑誌では「空間」 という概念は住宅の分析に最初に導入されたと考えられ るが,·1940年代には日本の伝統的建築を語る際に使わ れた例も見いだすことができる。それを行ったのは井上 充夫と浜口隆一である。

井上は「建築雑誌』1943 年 4 月号に掲載された「我 国上代建築の配置及び平面に見る空間把握の方式に就い て」の「論文梗概」(pp.332-333) で, 日本の上代の建 築の平面や配置の形式に「平行座標式空間把握方式」と 「極座標式空間把握方式」があり，「我国上代建築に於 ける空間把握の方式は常に一貫して縦軸式より横軸式 へ, 極座標式より平行座標式へと転化した事」(p.333) を主張している。

また, 浜口は『新建築』1944 年の 1 月号, 4 月号, 7 月 8 月合併号，10月号に連載した「日本国民建築様式 の問題」で,「建築とは行為的 =空間的要素と構築的 $=$ 物体的要素との何らかの統一体」であり,「西洋の建築 意欲は伝統的に構築的＝物体的要素に傾倒してゆき，日 本の建築意欲は伝統的に行為的=空間的要素に傾倒して いった」こと，そして「阳本国民建築様式の問題は，わ れわれの作る建築の行為的=空間的要素の形成の仕方に その主たる場所を見出さなければならない」ことを主張 している(0)。

ここで注目すべきは，2人の理論の妥当性ではなく， 「空間」という概念を持ちこむことによって日本の伝統 的な建築に新しい認識をもたらそうという意識である。 ここでも「空間」が建築を語る上での一つの主要な概念 として展開されているのを見ることができる。

\section{1950 年代の丹下健三を中心とするグループによる「空 間」を活用した建築論の展開}

新建築」を見ると，1950年頃から「空間」や「スペー ス」という語を用いた記事が多くなるのがわかる。

「空間」という語が用いられた記事の数がその年の『新 建築」の総記事数に占める割合を見ると, 1948 (昭和 23) 年が $10 \%, 1949$ 年が $20 \%, 1950$ 年が $33 \%, 1951$ 年 
が $40 \%$ と増加し，それ以後は1955（昭和 30）年まで 毎年 $40 \%$ 以上になっている。

『建築雑誌』でも似たような傾向が見られる。『建築雑 誌』において「空間」，またはそれに類する語を用いた 記事の数は 1946 （昭和 $21 ）$ 年が 4 件, 1947 年が 3 件, 1948 年が 7 件, 1949 年が 11 件, 1950 年が 23 件, 1951 年が 34 件, 1951 年が 34 件, 1952 年が 35 件, 1953 年 が 24 件, 1954 年と 1955 年がともに 31 件となっている。

これらの雑誌において 1950 (昭和 25) 年頃から「空間」 及びそれに類する語が増えるのは，記事の内容や編集方 針の変更などの他の要因があるためではないか，という 反論があり得るだろう。また，戦前においても『新建築』 や『建築雑誌』では「空間」という語を用いた記事が 20 件程度あった年があるのだから，1950 年からの記事 数は「増加」というほどのものではないのではないか, という指摘があるかもしれない。しかし，1950年以降 においては記事の数が増えたというだけではなく，一つ の記事の中で「空間」あるいはそれに類する語は頻繁に 登場し，1冊の雑誌に掲載された「空間」という語を悉 皆的に拾い出すのに困難を感じるほどなのである。単に 記事の数だけではなく，登場する頻度が多くなったとい うことである。1950 年以後は「空間」やそれに類する「ス ペース」は日本の建築家の日常用語になった感がある。

その中には戦前と同様，欧米の建築文献の翻訳として 登場する例も多い(特に『新建築」)。戦前においてはヨー ロッパ，それもドイツ語圏のものが多かったと考えられ るのに対して, 戦後の場合は“Progressive Architecture” や“Architectural Record”など，アメリカの建築雑誌 の記事を翻訳したものが多い"11。

もちろん，「空間」という語が日常的に使用されるよ うになったからといって，「空間」という概念で建築を 語るやり方が一般化したとはいえない。一般的には「空 間」という語が，「気持ちのよい空間 $]^{12)}$ とか,「伸びや かな空間 ${ }^{(3)}$,「大きな空間」(1) ,「四角い空間」(5) のように, ある場の雾曲気や形状などを描写するのに用いられたに すぎない例も多い。このような表現法は昭和戦前にも散 見されたものである。

しかし，その一方で，戦後には「空間」という概念を 用いて建築を語るというやり方は着実に浸透していった と考えられる。1940年頃に西山外三によってはじめら れたと考えられる「行為」とそれが行われる「場」との 対応を示すために「空間」という概念を適用するという やり方は戦後になると他の建築家・研究者の論文や記述 にも見いだせるようになる。たとえば，池辺 陽や清家 清などの建築計画関係の論文には「純粋動線空間」(6),「家 事労働の空間」(17)，「家族の空間」18)などのような表見を 見ることができる。また，以下に示すような記述からは， 「空間」という抽象的な概念を導入することによって機
能を軸に住宅の構成を新しい観点から見ることも可能に なったことがうかがわれる。

「生活機能が住機能として, 住宅の内部にとり入れられるた めにはその機能の利用度が大であることが必要である。又利 用度の大きいものから順次，住空間に占有空間を獲得し，住 空間は分化してゆく。」

清家清「住宅 2. 平面について」(「新建築」1952 年 2 月号, p. 206)

しかし，1950 年代の『新建築」を見る限り，「空間」 という語を最も多用しただけではなく「空間」という概 念を最も巧みに活用したのは丹下健三と彼を中心とする グループ (丹下研究室) ${ }^{19)}$ であった，と考えられる。

彼らは「空間」を建築を把握したりそのあり方を考察 するときの主要概念として用いた。当時の建築を批判的 に乗りこえることをめざすときにも，日本の建築的伝統 を語る際にも，あるいは都市と建築の関係を説明する際 にもこの概念を用いた。彼らによって「空間という立場 で考え」20)ることは建築を語るときの基本的な枠組で あったと考えられ，それで建築を，あるいは都市をも， 統一的に理解しようとしていた。

たとえば，彼らは当時の建築界の状況を批判的に分析 しつつ彼らのめざす建築の正当性を主張するのに「空間」 を使っている。1955（昭和 30）年頃の彼らの発言を見 ると,「機能」と「表現」に対する「功利的な合理主義 の立場」と「それに続く機能主義の立場」，そして「い わゆる社会主義リアリズムの陣営」を「一面性の抽象」 または「二面性の野合」として批判している21。とりわ け当時影響力があったと思われる機能主義に対して彼ら は次のような批判を加えている。

「見在われわれの考えている空間ともっとも激しい対立関係 にあるものは機能主義であると思われる。いわゆる機能主義 建築の方法というものが個個の建築の要求する機能を個別的 に分析しこれにもとづいて空間のあり方を制限し，規定し， その限りで個別的要素の集積としての全体を合理的に構成し てゆこうとする，いわば限定的な方法であったとわれわれは 解するのであるが，これがわれわれの方法と対立するという のはいかなる意味なのか」

沖 種郎ほか「コア・システム一空間の無限定性」(「新建築」 1955 年 1 月号, p. 57)

ここに引用した論文の中で, 彼らは前川建築事務所の国 会図書館計画案（1954 年）を例に，そこには「ブロッ ク構成においても平面においても，建築一般よりも図書 館・図書館一般よりも国会図書館というぎりぎりの限定 性に立脚した特殊解であり，空間一般についての追求が 全くない」(p.57) と批判している。そして「建築にお いては必らずある限定的な要素一シャフト・構造等一が 出てくるわけだが，此等の限定的な要素を本来無限定で あるべき 1 次空間から排除しようという要求がコアーシ ステムを生んだといえる」(p.57) と，コア・システム 
の優位を主張している。丹下はこのような「空間におけ る限定と無限定」22!，関係を建築について考察する上で の重要な問題として以下のように記している。

「生活を伝統と進歩との, 私的なものと社会的なものとの交 錯した抵抗的な発展として, 動的に見る立場からすれば, 空 間における限定性と無限定性, 同時性と永遠性の問題に目を 向けなければならないであろう。」

丹下健三「現在日本において近代建築をいかに理解するか」 (『新建築」1955 年 1 月号, p. 16)

さらに丹下らは自らの創作の手がかりとして「空間の 典型化」という考えを提唱した。彼らは「その時々の条 件を分析しながら，そこからもっとも有望な要素を抽出

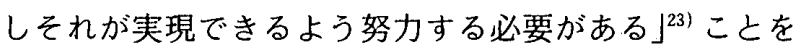
主張し，設計に対する両極のアプローチ，すなわち機能 主義者流の《はじめに機能がある》とミースのユニ ヴァーサル・スペースのようなくはじめに空間がある》 という設計に対する両極のアプローチ，は実際には「お そらく繰返し繰返し相互のアプローチがつみあげられ て，遂に分かち難く結び合った時に，すなわち典型的な 空間に到達する」とする。たとえば，「オフィスの執務。 空間はその範囲内では極度のフレキシビリティを要求し ている」ように，「個々の機能分化を明確化して，あら かじめいくつかに類型化しておくことが個々の機能の典 型化を促進することにな」り，「空間の典型化」とはそ

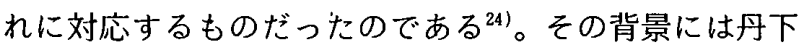
健三の「健築家が機能の本質をつかむということは, 無 媒介には不可能であって, 空間を媒介として, はじめて

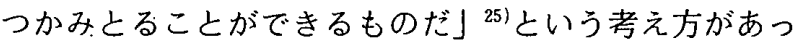
たと見られる。

以上のように，当時の建築の状況を批判的に乗りこえ つつ自らの考えを展開するに際して，丹下健三を中心と するグループは「空間」という概念を活用しているので ある。

また, 丹下らはこの頃「社会的空間」,「私的空間」と いう語も用いている。丹下は上揭の論文「現在日本にお いて近代建築をいかに理解するか」(陪建築」1955 年 1月号) の中でそれが意味するものについて簡単な説明 を加えている。それによれば，「わたくし達の現実の生 活の中には, また私的二経済的立場と, 社会的立場とが 抵抗しつつ交錯して」おり，これを「建築的に即して考 えてゆくとき, 内部機能と外部機能とでも呼びたいもの を認めないわけにはゆかない。(中略) そうして, 内部 機能のなかに私的なもの，あるいは私的経済的な立場か らする機能を考え，外部機能を社会的立場からするもの と考えて, (中略), 私的空間と社会的空間とか, 私的尺 度と社会的尺度とかいうことばを使ってきた」というこ とである(p.16)。

丹下らは創作に際してこの「社会的空間」をも認識す
べきことを主張している。彼らは「個個の建築のもつ内 部機能をより高度に発達せしめ, かつそのおのおのは地 上にもつ社会的空間の連続にようて，その建築の社会に 位置する社会的相互関係を見出し，私たちの社会的連带 の場として,より建築的たらしめようとする $\rfloor^{261}$ 。そして, 「以上私たちが今までに取組んできた建築はそのいずれ もがピロティによって形づけられる空間を社会的利用に 提供してきた」とあるように，ピロティはこの「社会的 空間」の一例として位置づけられている。ここで注目し たいのはその理論の妥当性ではなく，「空間」という語 によって建築とその周囲が関係づけられていることであ る。ここには建築と都市を「空間」という一つのカテゴ リーのもとに統一的に把握しようという姿勢が見られ る。逆にいえば,「空間」という概念を導入することによっ て建築と都市を一体的にとらえることができるように なったということである。倉敷市庁舎（1960 年）竣工 時に丹下健三が記した次の文章にはそのような思考が展 開されているのを見ることができる。

「もっともこのスケールが，十分にヒューマン・スケールの 末端にまでは,達していないことも認めなければならないが, これらのスケールの sequence 序列づけによって, 広場一市 庁舎一内部空間にいたる空間のオーガニゼイションを,さら に市庁舎一広場一民家にいたる都市空間の hierarchy を考え てみたかったのである。」

丹下健三「建築・都市にういて」(「新建築」. 1960 年 9 月号, p. 58)

ティームXの影響を受けたものと思われるが，「空間」 という概念で建築・都市を階層的にとらえようとしてい るのが注目される。

1950 年代の日本の建築界に「伝統論争」があったこ とはよく知られている。丹下らはそこでも「空間」で日 本の建築的伝統を理解しようとしている。当時, 池辺陽 は「丹下健三氏は日本の伝統を空間の無限定性という定 義をしている。日本の建築の開放性，自由性などについ ては今までもしばしばいわれてきたことであるが，丹下 氏はそれを無限定性という語によって見事にとらえ た」と77記している。丹下自身は日本の建築的伝統に対 して次のように述べている。

「私が伝統に対してとっている考えは，伝統の中の表現につ いては否定するが，形とか空間という方法的に積み上げられ て来たものは蓄積し得るもの, 継承し得るものとすることで す。例えば柱と梁から構成される空間にはいろいろな表現が ある。素朴な表現もあれば“わび”たものもあり，“文” なものもある。しかし空間取扱の方法に基本的な違いはなく， 形は同じなのです。」

「現代建築の探究」(「建築雑誌】1956 年 11 月号, p. 14)

丹丹下は以下のように，「もののあわれ」や「わび」，「さ び」などを素朴に継承することには疑問を呈している。

「木造の柱一梁と畳によって構成される空間には“もののあ われ”から“さび”にいたる創造の姿勢と，そこから生れる 
表現をまとっているものがある。この日本建築の空間の開放 性やそれにまとわりついている，はかない，移ろいやすい， か弱い表現の中には，消極的な自然観があることもすでに指 摘したとおりである。畳をとって見ても，そこには“わび” “さび”や“風流”の表現がまつわりついているのである。」 丹下健三「現代建築の創造と日本建築の伝統」(「新建築」 1956 年 6 月号, p. 36)

丹下はそれを単純に認めるのではなく，「前向きの姿勢 に立った健康な生活の知恵が, ながい歴史の過程のなか で創造し獲得してきたところの方法的成果ももってい る」(同上，p.36）ことを重視し，それを継承すること を提唱している。その具体的なコンセプトとして上げら れているのは「空間の典型化」である。先述のように, これは丹下を中心とするグループにとっての当時の最重 要課題の一つであり, それを伝統の理解・継承にも展開 したにすぎないとも受けとれるが，伝統をも「空間」と いう概念で理解しようとした点は注目される。

以上のように，丹下健三を中心とするグループは 1950 年頃に「空間」という概念を建物単体だけではなく, 建築と都市の関係や日本の建築的伝統を理解する際にも 展開して, 自らの建築理論をつくりあげていた。ここで は「空間」という抽象的・普遍的な枠組が一貫して活用 されている。いいかえれば，丹下グループは建築や都市 の本質を「空間」に見ているわけである。『建築雑誌』・ 『新建築』・国際建築』を見るかぎり，彼らほぎこの概 念を多様に駆使したものは見当たらない。彼らが日本で この概念を活用した最初のグループの一つであったこと はまずまちがいなかろう28)。『建築雑誌』1960 年 12 月 号には同年 10 月 22 日に行われた日本建築学会研究協議 会「作品を通しての建築論」(pp.691-693) の丹下健三 と谷口吉郎の講演要旨が揭載されている。その中で丹下 は彼の建築論をすべて「空間」を使って説明している。 同じ時に講演した谷口吉郎の講演趣旨に一言も「空間」 が登場しない299のと対照的である。

丹下グループのこのような活動によって日本の近代建 築は新たな段階に達したと考えられる。すなわち，それ は「空間」という抽象的・普遍的な概念で建築や都市を 語るやり方やその概念を設計の主要テーマにすえるやり 方がこの頃広まりはじめたことを示しており，それはま た日本の建築界への近代合理主義的思考法の浸透過程の 一断面を示していると考えられるのである。

\section{5. 結 論}

本研究は「空間」という概念で建築を語るやり方が日 本の建築界に導入された経緯やそこに見られる特徵を分 析することを通して, 日本の建築界における近代合理主 義，およびそれを理論的基盤とする近代（主義）建築の 導入や理解のされ方の一端をさぐろうとしたものであ る。日本近代の建築界における代表的な雑誌である「建
築雑誌』・建築世界】・『国際建築』・『新建築』の 1887 年から 1960 年までの記事を主な対象に，その記事に登 場する「空間」やそれに類する語を含む記述を収集・分 析し，下記のことを明らかにした。

明治時代・大正時代においては「空間」あるいはそれ に類する語はまれにしか登場しない。その中で「空間」

は「物と物との間」「すきま」「「あるとまりを持った ひろがり」という意味で使われていることが多い。その 他には「空間芸術」とか「空間感情」のように, ドイツ 美学・美術史の影響を受けていると思われる使われ方が 散見される。

昭和初期においては登場頻度が高くなるものの, 上記 のような傾向は同様に見られる。欧米の著作の翻訳や欧 米の建築家に言及するときに「空間」という語が用いら れていることが多いのが特徴といえる。このことは「空 間」が外来のもので，欧米の建築や建築家を語ることを 通して, またドイツ美学・美術史の影響を受けながら, しだいに日本の建築界に浸透していったことを示唆する ものと考えられる。

昭和初期にはわずかではあるが、「空間」を建築を語 る際の主要概念にしようとしたものを見いだすことがで きる。その先駆者として元良 勲・山田 守・川喜田煉 七郎・西山外三らを上げることができる。特に西山が 1940 年頃にある行為とそれが行われる場との対応を示 すためにこの語を用いたのは注目される。このやり方は 戦後に他の研究者によっても展開された。この西山の貢 献が示すように，「空間」を主要概念に建築を分析する やり方は, 今回対象にした雑誌記事から見る限り, 住宅 の機能分析に最初に導入されたと考えられる。しかし， このやり方を導入した建築家の一人である川喜田煉七郎 がこのようなやり方を他の建築種には展開していないこ とが示唆するように，「空間」はこの時期にはまだ「借 り物」のレベルにとどまることが多かったと見られる。

1940 年代前半には井上充夫や浜口隆一によって, 日 本の建築的伝統を理解するのに「空間」という概念が用 いられた。

戦後, 特に 1950 年代から「空間」という語は建築文 献に頻繁に登場するようになった。その中には戦前と同 様,「物と物との間」,「すきま」,「あるまとまりを持っ た広がり」という意味で使われただけのものが多い。欧 米の文献の翻訳にもしばしば登場するが, 戦後において はアメリカの建築雑誌の記事を翻訳したものが多い。

1950 年代に「空間」という語を最も多用しただけで はなく「空間」という概念を最も巧みに活用したのは丹 下健三と彼を中心とするグループ (丹下研究室) だった と考えられる。彼らは建築論・都市論を展開する際にも， 日本の建築的伝統を理解する際にもこの概念を活用し た。彼らは建築や都市, 伝統をすべて「空間」という抽 
象的・普遍的な概念で理解しようとしたのである。その 基調をなす考え方は「空間における限定性と無限定性」 や「空間の典型化」であった。彼らの活動を通して「空 間」という抽象的・普遍的な概念で建築や都市を語るや り方やその概念を設計の主要テーマにすえるやり方がこ の頃日本の建築界に広まりはじめたと考えられる。そし てそこには日本の建築界への近代合理主義的思考法の浸 透過程の一断面を見ることができる。

註

1）【新建築」は日本建築学会図書館・新建築社・京都大学建 築学教室図書室所蔵, 藤岡私蔵のものを用いたが，下記 の号は発見できず，今回の調查には含められなかった。 第 1 巻第 12 号, 第 2 巻 5 号, 第 3 巻第 4 号, 第 4 巻第 6 号. 7 号. 12 号, 第 5 巻 2 号. 4 号. 7 号. 8 号. 11 号. 12 号, 第 6 巻 2 号 $\cdot 4$ 号 $\sim 12$ 号, 第 20 巻第 11 号

2）「建築世界」における「空間」の初出は1909（明治 42） 年 5 月号揭載の三戸観仏房「建築家としての職分 (其二)」 でそこには以下のように「空間」が用いられている。 「建築には自加方面がある，空間的にいへば実用的 と鑑賞的との二つである,」(p. 29)

3）伊東忠太：日本建築術に於ける曲線の性質を論す(承前), ([建築雑誌」p. 348，1894 年 12 月号)

4）大江新太郎：満州に於ける建築装飾に就て，([建築雑誌】 p. 14,1908 年 10 月号)

5）「独逸建築略史（四）」(「建築世界」1920年 1 月号)に下 記のように「空間感情」，「空間観念」という語が用いら れている。

・「尤も最初の間は古代の遺蹟に渠れら独特の空間感情 を加味するに過ぎなかったが，中世紀になっては完全 自覚した運動を興すやうになった。」(p.42)

-「然して此等の時代に於ける空間観念の発展と技術の 進歩とは大体三段階をなして行はれてるる。(p.42)

6）KEN TKD：安井邸を訪ふ日の記，(「新建築」p. 282, 1931 年 8 月号)

7）岸田日出刀が 1928. 年 6 月から 9 月にかけて [建築䧴誌】 に連載した「欧州近代建築史論」は 252 ページにわたつ てヨーロッパ近世の建築史について説明したものだが, その中で「空間」という語は全部で 5 回しか登場しない。 その中の 4 回は「形の峻厳, 比例の純粹性と確固性, 広 闊なる空間, 此の如きは精神的にも又実際的にも，最も 上く当時の新教 (PROTESTANTISMUS) の福音教義 に合致適応したものであった」([建築雑誌】p.11, 1928 年 7 月号) のように, ドイッ・バロックに関するもので, その 1 つは明らかにドイッ文献の引用である。最後の 1 回はフランス・バロックに関するものだが，そこでは「第 一及び第二の天井の間に相当の空間があり」(同前, p. 53) と「物と物の間」を意味するにすぎない。この論稿の最 後には参考文献が上げられており，その中には“Die Architektur der Barock und Rokokozeit in Deutschland und der Schweiz”なよ゙のドイツ語文献がある。したがっ て, この岸田の論稿のドイッ・バロックの項に集中して 「空間」が現れるのはこのようなドイッ語の文献に頼つ たせいではないか，すなわち，「空間」がドイツ美学・美 術史の影響を受けて日本の建築界に浸透していたことを
うかがわせる。

8）「住居の基本空間に対する一考察」(健築と社会」1941 年 4 月号), 「極小住宅に於ける平面基蕉の問題 (同前, 1941 年 10 月号),「住居空間の用途構成に於ける食寝分 離論」（日本建築学会論文集，1942 年 4 月）など。なお， 「住居の基本空間に対する一考察」(前出)では, 「就寝空 間」ではなく、「寝室空間」という語が使われている。

9）川喜田はアレキサンダー・クラインの住宅分析方法を日 本に紹介している。それは「国際建築】1 930 年 4 月号・ 5 月号の「アレキサンダー・クライン氏の小住宅平面の 研究」, 同誌同年 12 月号の「ア・レキサンダー・クライン の住宅平面の考察に就いて」などである。その中で「空間」 という語が用いられているのを見ることができる。

10）【新建築」p. $271, .1944$ 年 10 月号

11) たとえば，「どんな建物が美しいか」(新建築」1948年 9 月号, ジョセフ・ハドナットの講演を翻訳したもの), 「ブルース・ガッフ (Bruce Goff)一合衆国中西部の建築 家一」(新建筑」1948 年 10 月号, “Architectural Forum” 1948 年 3 月号の記事の翻訳) など

12）設計：LV グループ「あすか保育園」(「新建築」p. 31, 1954 年 8 月号)

13）「日本建築学生会議 コミュニティーセンターの設計競 技」([国際建築」p. 54，1957 年 11 月号)

14）設計：海老原建築設計事務所「大日本インキ製造株式会 社＼cjkstart東京工場㹡張計画」(「国際建築」p. 46，1954 年 5 月 号)

15）設計：広瀨鎌二建築技術研究所「事務所十商店」(「新建築」 p. 519,1952 年 11 月号)

16）池辺 陽：図式による住宅組織の分析，(【新建筑」p. 47, 1953 年 1 月号)

17）清家 清: 住宅平面の傾向, (「建築雑誌」p. 13,1953 年 4 月号)

18）同上, p.14

19）「丹下健三と彼を中心とするグループ」というのは，丹下 健三のほかに,「丹下研究室」「「東京大学丹下研究室」· 「丹下研究室グループ」・「丹下健三計画研究室」の名のも とに登場する人物や，丹下健三設計の作品の設計主旨な ぞを書いている人物，丹下健三とたびたび連名で登場す る人物であり，その氏名は下記のとおりである。 丹下健三, 浅田 孝, 磯崎 新, 大谷幸夫, 沖 種郎, 神谷宏治, 黒川紀章, 小㚘貫一, 杉 重彦, 田良島昭, 長島正充, 馬渡俊郎, 光吉健次, 茂木計一郎, 吉川 健 (丹 下以外は 50 音順)

20）丹下健三：建築・都市について，(新建築」p. 55，1960 年 9 月号

21）丹下健三：現代建築の㓣造と日本建築の伝統，(新建築」 p. 29, 1956 年 6 月号)

22）ちなみに，[国際建築」1954 年 9 月号のカルロ・アイモ ニ一ノ「生活をあたらしく理解する 現代建築と国民的 伝統：1954 年国際建築学生会議の基調報告」に「自動性 に対する理想の, 没趣味な繰返えしに対するファンタジー の, 無限定性に対する限定空間の勝利であります」と,「空 間の限定性と無限定性」とよく似た表現が見られる。

23）「創作論定着への試み 丹下研究室報告 1956.6」(「新建 築」p. 80,1956 年 6 月号)

24) 同上 
25）丹下健三：図昦印刷原町工場の受賞にさいして，(『建築 雑誌」p. 14, 1955 年 7 月号)

26）大谷幸夫ほか：ピロティー社会的空間一, (『新建築」p. 61, 1955 年 1 月号)

27）池辺 陽：和風建築と現代のデザイン（「新建築」p. 69, 1955 年 6 月号)

28） 1955 (昭和 30 ) 年の前後 3 年間の『建築雑誌』・新建築」· 国際建築」で「空間」という語が登場する記事の数はあ わせてそれぞれ，1952 年 139 件，1953 年 140 件，1954 年 109 件, 1955 年 190 件, 1956 年 202 件, 1957 年 158 件, 1958 年 175 件で，そのうち丹下健三と彼を中心とするグ ループによるものはそれぞれ 3 件, 5 件, 7 件, 14 件, 8 件, 10 件, 10 件と, 数でいえばけっして多いわけではない。
注目されるのはその適用の仕方であり，今回対象にした 雑誌では，彼らほどこの概念を巧みに駆使した建築家を 見出すことはできなかった。

29）谷口吉郎は「建築雑誌」1938 年 1 月号の「建築意匠学・ 序説」で「建築を単に構築と解さず，芸術と見んとする この立場によれば，建築の本質は空間形成にありとなし， 建築の物質性はこれによって美化され，斯くすることに よって, 初めて建築は芸術としての特性を獲得するもの と考へられてるる」(p.16) のように，戦前から「空間」 という語を用いていたが，その後それを自らの意匠論や 建築論に積極的にとり込むことはしなかった。

(1992 年 7 月 10 日原稿受理, 1993 年 2 月 2 日採用決定) 